\title{
The Use of Tayammum Pack to Reduce Number of Bacterial Colonies
}

\author{
Sunardi Sunardi*, Khaera Ummatin and Zaqqi Ubaidullah \\ Departement of Nursing, Faculty of Health Science, University of Muhammadiyah Malang, Indonesia \\ Jalan Bendungan Sutami 188A, Kota Malang, 65145 \\ *Corresponding author: sunardinadhif@yahoo.co.id
}

\begin{abstract}
Background: Patients hospitalized could experience spiritual distress for praying because of ablutions obstacle. One of holistic care is fulfill of spiritual needed patients and one of alternative to ablutions is tayammum pack (dust made of pure clay), unfortunately there are many differences perception that dust as ablutions for patients. Objective: The aim of this study to understand the effect of tayammum pack used on skin hygiene. Method: Study design used one-group pre-experimental prepost test design. Sixteen patients participated on this study. Result: Paired t-test analyzed showed significance level 0,034 ( $p<0,05)$.There was significant effect that used from tayammum pack on skin hygiene. Average number of bacterial colonies (colony forming units 218.44) on the skin after application pack tayammum. Conclusion: Clay minerals in tayammum pack contains intrinsic antibacterial components, so the use of tayammum pack can improve hygiene on the skin.
\end{abstract}

Key word: Spiritual Distress, Tayammum Pack, Skin Hygiene and Bacterial Colonies.

\section{INTRODUCTION}

Inpatient patients may experience spiritual distress. Based on a study of 62 patients with hospitalized ACS, 58\% experienced spiritual distress (Russell, Brown, Edara, Smith, Marine \& Ziegelstein, 2014). Furthermore, in the study of 70 women diagnosed with hospitalized breast cancer, 27 (38.6\%) had spiritual distress (Caldeira, Sílvia, Timmins, Fiona, de Carvalho, Emília C, Vieira, Margarida, 2016).

Nurses view patients as bio-psycho-sociocultural and spiritual beings who respond holistically and uniquely to health changes (Hamid, 2008). Spiritual needs is an element of the quality of nursing care. Nursing care spiritual has found effective in developing coping strategies for the patient. Patients will experience peace and spiritual nursing care will lead to a patient's positive view of life. In addition, the spiritual health care also have a positive effect on physical and psychological health of the patient. When needs spiritual and emotional patient met, it will increase patient satisfaction (Cetinkaya, Dundar, \& Azak, 2011).

Indonesia is the biggest Muslem population in the world. In 2010, it is approximately up to $88.1 \%$, equivalent to 205 million Muslims on a worldwide scale.Muslims and prayers can not be separated in living their lives because it is a duty that must be run even in a state of illness. If a Muslim leaves the prayer then he sins even in sickness. Therefore, if hospitalized patients can not pray, it will be a problem of their own or will experience spiritual distress. The patient will feel guilty.

One of the actions of nursing in the fulfillment of spiritual needs in the patient ie, facilitate to pray five times. However, the fulfillment of spiritual needs can not be met in the hospital (Zahwa, 2010). The results of research conducted on inpatients at Aisyiyah Bojonegoro Hospital and Haji Surabaya Hospital showed that not all patients did pray (Bakar 
\& Kurniawati, 2013). This is due to physical weakness and unholy conditions. And also based on research done on 150 patients colostomy (40.7\%) and ileostomy (59.3\%) hospitalized found that $25.2 \%$ of patients decreased to pray 5 times. This is due to the perception of cleanliness and holiness (Akgül, Betül; Karadağ, Ayişe, 2016).

One of solution this problem use Tayammum to perform ablution. Tayammum substitute for ablution that should use clean water but it is replaced by using clean soil or dust. Fortunately, some hospitals have been facilitated to perform ablution using tayamum (purification by using dust), one of them is in hospital Aisyiyah Bojonegoro. In the hospital it facilitates with tayammum pack. However, there is a perceptual difference regarding the use of dust for tayamum regarding safety in its use in sick people due to considering sterility. Therefore, researchers wanted to explore whether the use of tayammum pack can affect the hygiene of the patient's hospitalized skin.

\section{METHOD}

This study was performed in a hospital inpatient Arofah Aisyiyah Bojonegoro, East Java Indonesia and continued in Biomedical Laboratory Faculty of Medicine, University of Muhammadiyah Malang East Java Indonesia on January 13 and January 16, 2016. Design Pre-experimental study using a prospective approach to design using one -Group pre-post test design. Samples in this study amounted to 16 samples at a sampling nonprobability approach with a purposive sampling technique. Inclusion criteria in this study included patients who were not treated for long periods, had no skin infections, no dust allergies, no contact with soap or antiseptics, and patients who were not in a coma. The instrument used in this study was the measurement of in-vitro biofisiologis ie, taking the skin as a mucosal swabs samples microbiological examination (SOP).

The steps in the implementation of research as follows,

1. Preparing media blood agar plate in petridish and save on storage media

2. Coordinate with room head and nurse room at Arofah's in-patient ward

3. Ensure that the sample is willing to be the respondent in the study by giving a letter of approval. If the respondent agrees, the researcher then explains to ensure the confidentiality of the data of the respondent.

4. Prepare a tool for sampling of the skin mucosal smear

5. Bring tools for making the skin mucosal swabs (sterile swab, $\mathrm{NaCl}$, and media blood agar plate in petridish

6. Petridish provide the code to differentiate mucosal swabs the skin before and after use tayammum pack

7. Ask the patient about the restrictions on the area of the hand that will be done tayamum

8. Taking the mucosal swabs the patient's skin prior to use Tayammum pack that is, before the patient was praying Maghrib (data pre)

9. Planting mucosal swabs skin samples on blood agar plate with media streak plate method

10. Store samples of skin mucous smear on storage media

11. Following patients do tayamum with tayammum pack to perform evening prayers and perform tayamum with tayammum pack for evening prayers

12. Petridish provide the code to differentiate mucosal swabs the skin before and after use tayammum pack

13. Ask the patient about the restrictions on the hand area that has been done tayamum

14. Taking the mucosal swabs the patient's skin after application pack Tayammum, 2 times a day that tayamum to pray Maghrib and Isha (data post)

15. Planting mucosal swabs skin samples on blood agar plate with media streak plate method

16. Saving mucosal swabs samples of skin after use tayammum pack on a storage medium 
17. Researchers would like to thank the respondents for their cooperation and time provided.

18. Bring a sample of skin-mucous smear to the laboratory

19. Doing incubation of bacteria for 24 hours in an incubator $1 \mathrm{x}$

20. Counting the number of colonies of bacteria before and after use tayammum pack

\section{RESULT AND DISCUSSION}

A total of 16 people participating in the study consisted of 11 women (69\%) and 5 men $(31 \%)$; minimum age 28 years; age max. 71 years; average age of respondent 51 years; non-school education (13\%), elementary (25\%), high school (37\%) and undergraduate (25\%). Based on the results of counting the number of colonies of bacteria in the mucosa of the patient's skin before and after use tayammum pack that is, before the use of tayammum pack was 681.5 , while the pack after use tayammum is 463.06.There is an average difference of 218.44 which indicates a decrease in the average number of bacteria colonies after use tayammum pack (table 1.1 and chart 1.1). There are differences in the number of bacterial colonies before use tayammum pack on respondents with young adults (28 years and 31 tahun) less than that of people aged over 40 years.

Kolmogorov-Smirnov normality test results by using SPSS version 22 indicates the PValue $>\alpha(0.05)$.Conclusion of normality with the Kolmogorov-Smirnov test showed normal distribution of data.Meanwhile, the result of paired t-test analysis with SPSS program, obtained t value $=2.340$ with significance level $0,034(\mathrm{p}<0,05)$, Sig value. $(2$-tailed $)<$ real level $(\alpha)$ so that it can be deduced that $\mathrm{H} 1$ is accepted, so it can be concluded that there is influence of use of tayammum pack to integumentary hygiene.

Table 1 Average Yield Counting the Number of Bacterial Colonies Before and After Use Tayammum Pack of Culturing Skin Mucous Swab Samples

\begin{tabular}{llll}
\hline Group & Groups before & Group after & Average difference \\
\hline Mean & 681.50 & 463.06 & 218.44 \\
\hline
\end{tabular}

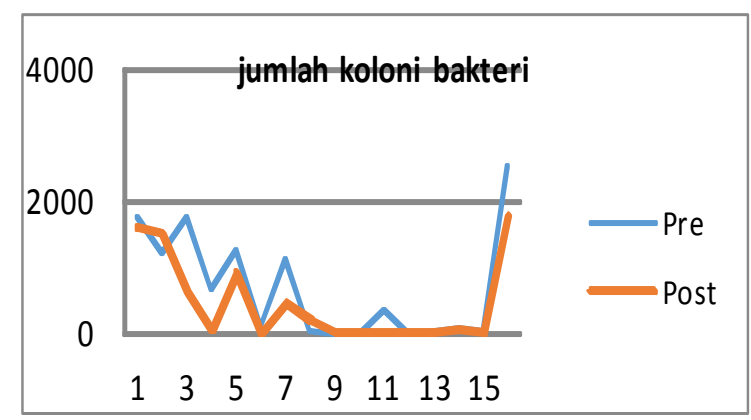

Figure $1 \mathrm{H}$ Acyl Counting the Number of Colonies of Bacteria in the Mucosa of the Patient's Skin Before and After Use Tayammum Pack 

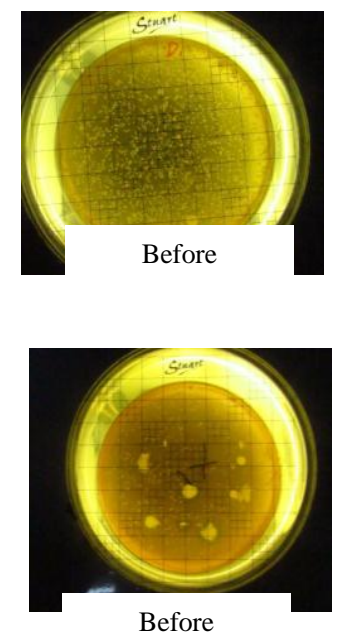
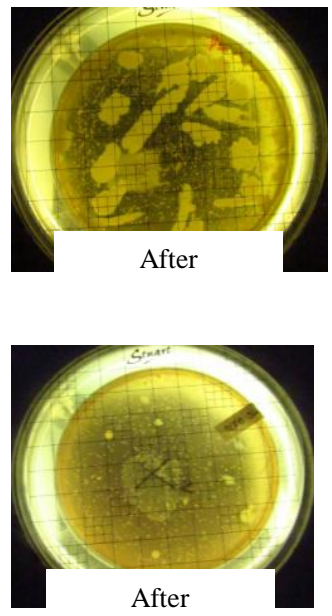

Figure 2 Samples of Counting the Number of Bacterial Colonies before and After Use Tayammum Pack

Tayammum pack is dust from clay that has been sterilized and used to facilitate the worship needs of patients at the Hospital Aisyiyah Bojonegoro. Haydel et al (2008) suggests that clay is one type of soil measuring $<2.0 \mu \mathrm{m}$, has a large surface, and consists of highly concentrated ions and minerals found on the surface of the clay. These clay minerals contain intrinsic antibacterial components. Antibacteria agent is a substance capable of inhibiting the growth of microorganisms, can even kill microorganisms (William et al, 2010). Antibacterial agent's have bactericidal, bacteriostatic, or combination effects of bactericidal and bacteriostatic effects (Haydel, 2008). According to Mosby (2008), bactericidal is an antibacterial effect that can cause bacterial death, while bacteriostatic is an antibacterial effect that tends to inhibit bacterial development or reproduction. Bacteriostatic prevents more bacterial replication and human coping mechanisms can fight bacteria in static amounts (Mims et al, 2007).

According to Greenwoods (2007), the mechanism of action of antibacterial agents is by disrupting the formation of bacterial cell walls, disrupting protein synthesis, disrupting the synthesis of nucleic acids, disrupting the integrity of membrane cells, or inhibiting the pathway of bacterial biosynthesis. Any injury to the cell wall or obstruction to the formation process will cause cell lysis. Antibacterial agents that have bacteriostatic ability will inhibit cell wall synthesis, so effectively used to fight bacterial growth. Antibacterial activity is also done by inhibiting the function of cell membranes. The cytoplasm of all living things is surrounded by the cytoplasmic membrane, which provides the permeability of the barrier, serves the active transfor, and controls the internal components of the cell. If the integrity of the cytoplasmic membrane is compromised, the macromolecules and ions will disappear from the cell and will result in cell damage and cell death.

Other antibacterial activity is done by inhibiting protein synthesis (inhibiting translation and transcription of genetic material) (Greenwoods, 2007). Bacteria have as many as $70 \mathrm{~S}$ ribosomes, while mammals have $80 \mathrm{~S}$ ribosomes. The subunits on each type of ribosome, chemical composition, and specific functions are different. Brooks et al (2001) explains that antimicrobial agents first attach to specific protein receptors, followed by inhibiting the normal activity of peptide formation (mRNA + formylmethionine + tRNA). Furthermore, the "recognition area" of the ribosome receives the wrong code from mRNA, an amino acid infusion occurs on the peptide that produces non-functional protein. Further 
attachment of antibacterial agents to specific protein receptors causes polysomes damage and will separate into monosomes. Overall, the antibacterial effect on protein synthesis causes irreversible effects (bacterial death). Other antibacterial activity is done by inhibiting nucleic acid synthesis. Inhibition of nucleic acid synthesis is performed by strong binding to DNAdependent bacterial RNA polymerase, which inhibits RNA synthesis.

The clay used as tayammum pack material is yellow brown. According to Lafi \& AlDulaimy (2011) three types of clay (white clay, gray clay, and yellow clay) have antibacterial effects against Staphylococcus aureus isolated from patients with skin infections, and have no effect against Pseudomonas aeruginosa isolated from patients with urinary system infection, but pink clay has an antibacterial effect against Pseudomonas aeruginosa and has a low antibacterial effect against Staphylococcus Aureus. Conclusions from the results of research conducted Lafi \& Al-Dulaimy shows that clay mineral can be an alternative treatment against bacteria that can cause infection in humans. According to Williams et al (2011), the comparison between the chemical content and the ability of exchangeable ions in clay minerals affects $\mathrm{pH}$ and oxidation states, controls water chemicals and contributes to antibacteria agents, which in turn can weaken bacteria. The $\mathrm{pH}$ and oxidation state maintained by clay mineralized surfaces is a key key to chemical control and redox (reduction and oxidation or electron transfer processes) associated with reactions that occur in bacterial cell walls.

There are factors that influence the ability of the clay as an antibacterial agent. According to Otto \& Haydel (2013), it is necessary to know the characteristics of clay minerals and chemical content on clay. This can be done using X-ray diffraction (XRD), inductively coupled plasma-optical emission spectroscopy (ICP-OES), and mass spectrometry (ICP-MS). The results of this Otto \& Haydel (2013) study indicate that ionic concentrations of clay $(\mathrm{Fe} 2+, \mathrm{Cu} 2+$, and $\mathrm{Zn} 2+)$ affect the ability of clays to be antibacterial. Clay mineral content, including clay mineral concentration, affects the ability of clay as an antibacterial agent by killing bacteria or inhibiting bacterial growth. Research conducted by Almeida et al (2014) found that dietary clays with different mineral types (basal diet, Smectite A $0.3 \%$, Smectite B $0.3 \%$, and $0.3 \%$ zeolite) and were administered to broiler chickens which have been infected with salmonella enterica have different capabilities in reducing salmonella enterica growth. According to Haydel, Remenih, and Williams (2008), cation exchange can eliminate the ability of $\mathrm{CsAg02}$ (one of the specific minerals of clay) to be an antibacterial agent. Some mineral elements lost during cation exchange are silicon (30\%), barium (35\%, and Strontium (45\%). The silicon concentration> $500 \mathrm{mg} / \mathrm{L}$ is toxic to E.coli.

\section{CONCLUSION}

Based on research conducted on 16 inpatients it can be concluded that there is a significant decrease of bacterial colony count before and after tayammum pack usage. Clay minerals in tayammum pack contains intrinsic antibacterial components. Antibacteria agent is a substance capable of inhibiting the growth of microorganisms and can also kill microorganisms. The use of Tayammum pack can improve hygiene on the skin so it is safe to use as an alternative to washing or before performing the prayer.

\section{ACKNOWLEDGEMENT}

This work was supported by Health Science Faculty grant and Muhammadiyah Malang University. The authors thank the patients who participated in the study and the nurses at the Aisyiyah Bojonegoro Hospital. 


\section{REFERENCES}

Al Ghamdi, KM, Alhomoudi, FA, Khurram, A (2014), Skin care: Historical and Contemporary Views, Saudi Pharmaceutical Journal, Vol.22, pp.171-178.

Almeida, J, A, S., Ponnuraj, N, P., Lee, J, J., Utterback, P., Gaskins, H, R., Dilger, R, N., Pettigrew, J, E (2014 ), Effects Of Dietary Clays On Performance and Intestinal Mucus Barrier of Broiler Chicks Challenged with Salmonella Enterica Serovar Typhimurium and on Goblet Cell Function In Vitro, Poultry Science.Vol.93, pp.839-847

Babeluk, R., Jutz, S., Mertlitz, S., Matiasek, J., Klaus, C (2014), Hand Hygiene - Evaluation of Three Disinfectant Hand Sanitizers in a Community Setting.PLoS ONE, Vol.9, No.11.

Bakar, A., Kurniawati, N, D (2013), Phenomenology Study of Islamic Religious Worship Service Experience with Islamic Spiritual Approach at Aisyiah Bojonegoro Hospital and Haji Hospital Surabaya. Surabaya: Airlangga University.

Brooks, G, F., Butel, J, S., Morse, S, A (2001), Jawetz, Melnick,\&Adelberg `s Medical Microbiology. United States: Appleton \& Lange.

Brown, R, G., \& Burns (2005), Lectures Notes on Dermatology.Jakarta: Erlangga Publisher.

Carretero, M, I., \& Pozo, M (2010), Clay and Non-clay Minerals in the Pharmaceutical and Cosmetic Industries Part II.Applied Clay Science, Vol.47, pp.171-181.

Cetinkaya, B., Dundar, S, A., Azak, A (2011), Nurse Perceptions of Spirituality and Spiritual Care.Australian Journal of Advanced Nursing, Vol.31, No. 1.

Doufesh, H., Ibrahim, F., Ismail, N, A., Ahmad, W, A, W (2014), Effect of Muslim Prayer (Salat) and It`s Relationship with Autonomic Nervous System Activity.The Journal of Alternative and Complementary Medicine, Vol.20, pp.558-562.

Greenwood, D., Slack, R., Peutherer, J., Barer, M (2007), Medical Microbiology.UK: Elsevier.

Hamid, A, Y, S (2008), Anthology Care Nursing Mental Health. Jakarta : EGC.

Haydel, S, E., Remenih, C, M., Williams, L, B (2008), Broad-spectrum in vitro Antibacterial Activities of Clay Minerals Against Antibiotic-Susceptible and Antibiotic-Resistant Bacterial Pathogens.Journal of Antimicrobial Chemotherapy, Vol.6, pp.353-361.

Jumaa, P, A (2005), Hand Hygiene Simple and Complex.International Journal of Infectious Diseases, Vol.9, pp.3-14.

Lafi, S, A., \& Al-Dulaimy, M, R. (2011), Antibacterial Effects of Some Mineral In Vitro.Acad.J.biologists.Sci, Vol.3, No.1, pp.75-81.

Maryan, A, S., Montazer, M., Rashidi, A., Rahimi, M, K (2012), Antibacterial Properties of Clay Layers Silicate: A Special Study of Montmorillonite on Cotton Fiber. Asian Journal of Chemistry; Vol.25, No.5, pp.2889-2892.

McSherry, W., \&Jamieson, S (2011), an online survey of nurses' perceptions of spirituality and spiritual care.J Clin Nurs.Vol.20, No.1, pp.57-67.

Otto, C, C., \& Haydel (2013), Exchangeable Ions Are Responsible for the In Vitro Antibacterial Properties of Natural Clay Mixtures.PLOS One.Vol.8, No.5.

Wang, Y., \& Han, J. (2010), Interaction of Photosynthetic Bacterium, Rhodopseudomonas Palustris, With Montmorillonite Clay. International Journal of Engineering, Science and Technology, Vol.2, No.7, pp.36-43.

Williams, LB, \& Haydel, SE (2010), Evaluation of The Medicinal Use of Clay Minerals As Antibacterial Agents. Geol Int Rev, Vol.52, No.7, pp.745-770.

Williams, L, B., Metge, D, W., Eberl, D, D., Harvey, R, W., Amanda, G. (2011).What Makes a Natural Clay Antibacterial.Environ Sci Technol, Vol.45, No.8, pp.3768-3773. 
Williams, L, B., Haydel, S, E., Giese, R, F., Elber, D, D. (2008).Chemical and Mineralogical Characteristic of French Green Clays Use for Healing.Clays Clay Miner, Vol.56, No.4, pp.437-452.

Zahwa, A. (2010). Shalat When Difficult.Jakarta : Qultum Media 